\title{
EFFECT OF REPLACING MUSTARD OILCAKE BY LINSEED OILCAKE ON GROWTH PERFORMANCE OF NILE TILAPIA (Oreochromis niloticus, Linnaeus, 1758)
}

\section{Suraj Babu Ghimire and Rahul Ranjan}

Journal of Institute of Science and Technology

Volume 22, Issue 1, July 2017

ISSN: 2469-9062 (print), 2467-9240 (e)

Editors:

Prof. Dr. Kumar Sapkota

Prof. Dr. Armila Rajbhandari

Assoc. Prof. Dr. Gopi Chandra Kaphle

JIST, 22 (1): 10-16 (2017)

Published by:

Institute of Science and Technology

Tribhuvan University

Kirtipur, Kathmandu, Nepal 


\title{
EFFECT OF REPLACING MUSTARD OILCAKE BY LINSEED OILCAKE ON GROWTH PERFORMANCE OF NILE TILAPIA (Oreochromis niloticus, Linnaeus, 1758)
}

\author{
Suraj Babu Ghimire ${ }^{1, *}$ and Rahul Ranjan ${ }^{2}$ \\ ${ }^{1}$ Central Department of Zoology, Tribhuvan University, Kirtipur, Nepal \\ ${ }^{2}$ Corona of Agriculture, Chitrawan, Chitwan, Nepal \\ *Corresponding E-mail: surajghimire77@gmail.com
}

\begin{abstract}
This study was done to explore the effect of replacing mustard oilcake by linseed oilcake in feed on the growth performance of Nile Tilapia (Oreochromis niloticus). Mustard oilcake (MOC) was replaced by linseed oil cake (LOC) at three different level $0 \%, 50 \%$ and $100 \%$ to prepare three different types of diets. Diets were prepared with about $18 \%$ analyzed crude protein content. Fingerlings were kept in three happa with three replications for each diet in completely randomized design (CRD). Fish of average weight $5.31 \mathrm{~g}$ were stocked in happa having size $1.5 \mathrm{~m} \times 1.5 \mathrm{~m} \times 1.2 \mathrm{~m}$. The experimental fish were fed $3 \%$ of their body weight per day, once in the morning for five months continuously. No significant difference $(p>0.05)$ in final mean weight, final total weight, average daily weight gain (DWG), survival rate, extrapolated gross fish yield (GFY), extrapolated net fish yield (NFY) and apparent feed conversion ratio (AFCR) among different treatments were observed. Hence, linseed oilcake can be used as the substitute in the feed of tilapia, if it is locally available.
\end{abstract}

Keywords: Mustard oil cake, Linseed oil cake, Growth performance, Nile Tilapia.

\section{INTRODUCTION}

About $5 \%$ of total area of Nepal is occupied by different freshwater aquatic habitat (Bhandari, 1992).The Himalayas of Nepal are well known for their running and standing waters supporting more than 200 species of fish are described from the Himalaya drainage system of Nepal (Shrestha, 1995).

The total fish production of Nepal is 64900 metric ton in which fish production from aquaculture practice is 43400 metric ton and fish production from capture fisheries is 21500 metric ton (DoFD, 2014/2015).

Fish species such as Tilapia can be included for aquaculture production as it is suitable for warm water zone of terai for better growth and production. Tilapia is a common name for a large group of fish species within the family Cichlidae. Tilapia is classified into 3 genera, Tilapia, Sarotherodon and Oreochromis based on reproductive behavior (Teichert-Coddington et al., 1997). Nile tilapia is commercially cultured species around the world under genus Oreochromis.

Nile Tilapia was introduced to Nepal in 1985 and kept at various government farms for its evaluation (Panth, 1993). Two species of tilapia Oryochromis niloticus and O. mossambicus were introduced in Nepal for the first time from Thailand in 1985 (Shrestha, 1994).

Nile Tilapia (Oryochromis niloticus) is the most important fish species on account of its fast growth rate, easy to reproduction, resistant to disease and poor water quality, adaptability to a wide range of culture condition and high consumer acceptability (Macintosh \& Little, 1995). Worldwide it is named as Aquatic Chicken (Pillay, 1999 and Fitzsimmon, 2000). It has not reached the farmers to large extent for culture because of its prolific breeding behavior (Shrestha, 2004).

Nile Tilapia is a tropical species that prefers to live in shallow water. The lower and upper lethal temperatures for Nile Tilapia are $11-12^{\circ} \mathrm{C}$ and $42^{\circ} \mathrm{C}$, respectively, while the preferred range is from 31 to $36^{\circ} \mathrm{C}$. The females incubate egg in their mouth and can collect fries in mouth if there is any danger. Thus, it is considered as a prolific breeder and can over populate a pond in short time period. Various feed stuffs of plant and animal origin are being used to make supplemental feed for fish. Ingredients of plant origin like linseed oilcake and 
mustard oilcake are also used in industries to make aqua feed. Linseed meal or Linseed oilcake is the byproduct of oil production from linseed (Linum sps.), also called flaxseed. Linseed meal is a protein rich feed containing $31.5 \%$ protein, crude fiber $9.5 \%$, calcium $0.4 \%$ phosphorus $0.8 \%$ and ash $6 \%$ (Declercq, 2006). Linseed oil is predominantly composed of PUFA, C18:3 (linolenic acid or omega-3), C18:1 (oleic acid or omega-9) and C18:2 (linoleic acid or omega-6) (Mayombo et al., 1997 and (Sauvant et al., 2004). The protein profile of linseed meal is relatively poor in lysine. Linseed meal can be a source of protein in fish diets. However, due to its amino acid imbalance and the presence of anti-nutritional factors like mucilage, tannins, phytates, cyanogen phytoestrogen (Francis et al., 2001), use of linseed meal in fish feeds is limited.

Mustard oil cake is the byproduct which is generated after the extraction of oil from mustard seed. The composition of mustard cake varies with the variety of growing condition and processing methods. Crude protein content varies from about $20 \%-40 \%$, crude fiber $8.5 \%, 21 \%$ lipid, $8 \%$ ash and protein is rich in lysine and sulphur containing amino acid which are limiting in cereal protein (Devi \& Devi, 2011).

Mustard oilcake contains major ANF like tannins, glucosinolates, phytates and linseed oilcake also contain ANF like mucilage (Slominiski et al., 1999), tannins, phytates, antipyridoxine, cyanogen (Francis et al., 2001). However, these oilcakes are used as feed ingredients to make supplemental aqua feed in industries.

So, linseed oil cake and mustard oilcake both contain various nutrients as well as anti-nutritional factors to certain extent as in all plant protein sources and present study mainly aims to investigate the effect of replacing mustard oil cake with linseed oil cake in different proportions on growth performance of Nile Tilapia.

\section{MATERIALS AND METHODS}

Present experiment was conducted at Corona of Agriculture, Chitrawan-8, Shankar Chowk, Chitwan. The experiment was conducted in happa fixed in one of the commercial fish production pond.

Nine nylon happa of same size $1.5 \mathrm{~m} \times 1.5 \mathrm{~m} \times 1.2 \mathrm{~m}$ were used for experimental purpose. All these happa were suspended in three different clusters in a single pond. Pond was pre-limed and prefertilized. Happa in this pond were suspended by tying to bamboo poles with stone pieces as sinkers at the bottom. Freshwater from a bored tube well was filled in pond at regular interval to maintain the water depth of about $1.2 \mathrm{~m}$ in pond and $1 \mathrm{~m}$ in happa.

The experimental design for present research was completely randomized design (CRD) with three feeds as treatment T1 (Feed I), T2 (Feed II) and T3 (Feed III). Each treatment was replicated thrice in different cluster. Altogether 10 fish were stocked in each happa. Thus stocking density was 4.44 fish per sq. meter. Stocking was done on $17^{\text {th }}$ February, 2015.

Fingerlings of $O$. niloticus of mixed sex were collected from the production pond of "Corona of Agriculture" using a sein. Fingerlings were sorted and only uniform sized were selected for stocking. Individual weights of 10 fish were taken and batch weights of fish to be stocked in a happa were also recorded.

Three experimental diets were formulated using mustard oilcake, linseed oilcake, rice bran, maize flour and wheat flour as diet ingredients which were procured from local market. Vitamin and Mineral premix (Agrimin) was also mixed in each type of feed at the rate of $1 \%$. Crude protein content of different feed ingredients and formulated feed were analyzed by Kjeldahl method. Feed formulation was done using MS-Excel solver. Feed ingredients were mixed according to requirement and feed was prepared.

Table 1. Crude protein content of different feed ingredients.

\begin{tabular}{|l|l|l|}
\hline S. No. & Ingredients & Crude Protein Content \\
\hline 1 & Mustard Oilcake & $23.05 \%$ \\
\hline 2 & Linseed Oilcake & $22.75 \%$ \\
\hline 3 & Rice Bran & $10.01 \%$ \\
\hline 4 & Maize flour & $9.85 \%$ \\
\hline 5 & Wheat flour & $9.80 \%$ \\
\hline
\end{tabular}


Table 2. Ingredients used in different feeds.

\begin{tabular}{|l|l|l|l|l|}
\hline \multirow{2}{*}{ S. No. } & \multirow{2}{*}{ Ingredients } & \multicolumn{3}{|c|}{ Inclusion percentage } \\
\cline { 3 - 5 } & & Diet I & Diet II & Diet III \\
\hline 1 & Mustard Oilcake & 60 & 30 & 0 \\
\hline 2 & Linseed Oilcake & 0 & 30 & 60 \\
\hline 3 & Rice Bran & 20 & 20 & 20 \\
\hline 4 & Maize flour & 10 & 10 & 10 \\
\hline 5 & Wheat flour & 10 & 10 & 10 \\
\hline Assumed CP Content & 17.80 & 17.71 & 17.62 \\
\hline Analyzed CP Content & 17.60 & 17.50 & 17.50 \\
\hline
\end{tabular}

Feeding of fingerlings started from next day of stocking in happa. The experimental fish were fed at $3 \%$ of their body weight per day for five month continuously. Feed for next month was adjusted according to monthly weight sample. Feeding was done once early in the morning around 9.00 to $10.00 \mathrm{am}$.

All the fish in happa were scooped out using scoop net for growth check. Growth check of fish was done monthly during which weight record of individual fish was taken with the help of digital balance. This was done on morning time to avoid stress to fish. Mortality during a month period was also noted during sampling. Water quality parameters like temperature, dissolved oxygen (DO), $\mathrm{pH}$ and transparency in terms of Secchi's disc reading were studied weekly using various equipments.

Analysis of experimental data was done using the following formulae

$$
\begin{gathered}
\text { Daily Weight Gain }(g / \text { fish/day })=\frac{\text { Mean final weight }(g)-\text { Mean initial weight }(g)}{\text { Culture period }(\text { days })} \\
\text { feed conversion ratio }=\frac{\text { Quantity of feed intake }(g)}{\text { Net weight gain }(g)}
\end{gathered}
$$$$
\text { Net fish yield }\left(\mathrm{kg} / \mathrm{m}^{2} / \mathrm{yr}\right)=\frac{\text { total weight gain }(\mathrm{kg}) \times 365}{\text { culture area } \times \text { culture period }}
$$$$
\text { Gross fish yield }\left(\mathrm{kg} / \mathrm{m}^{2} / \mathrm{yr}\right)=\frac{\text { total final weight }(\mathrm{kg}) \times 365}{\text { culture area } \times \text { culture period }}
$$

$$
\text { Survival }(\%)=\frac{\text { Total harvested number }}{\text { Total stocked num ber }} \times 100
$$

Statistical analysis was done using SPSS (V 21.0). One way ANOVA was used to test the significant difference between the treatment means of different parameters at 5\% confidence level. DMRT (Duncan's Multiple Range Test) was applied to compare the means when there was significant difference among treatment means.

\section{RESULTS}

Growth of fish in different treatment showed almost similar pattern (Figure 1). There was gradual increase in average weight till April and after that it increased rapidly up to the end of experiment. Fish in T1 grew up to average final weight of $224.19 \mathrm{~g}$ 
from average initial weight of 5.91 g. Similarly, fish grew from average initial weight of $5.10 \mathrm{~g}$ and
$4.92 \mathrm{~g}$ to $231.81 \mathrm{~g}$ and $224.73 \mathrm{~g}$ in $\mathrm{T} 2$ and $\mathrm{T} 3$ respectively.

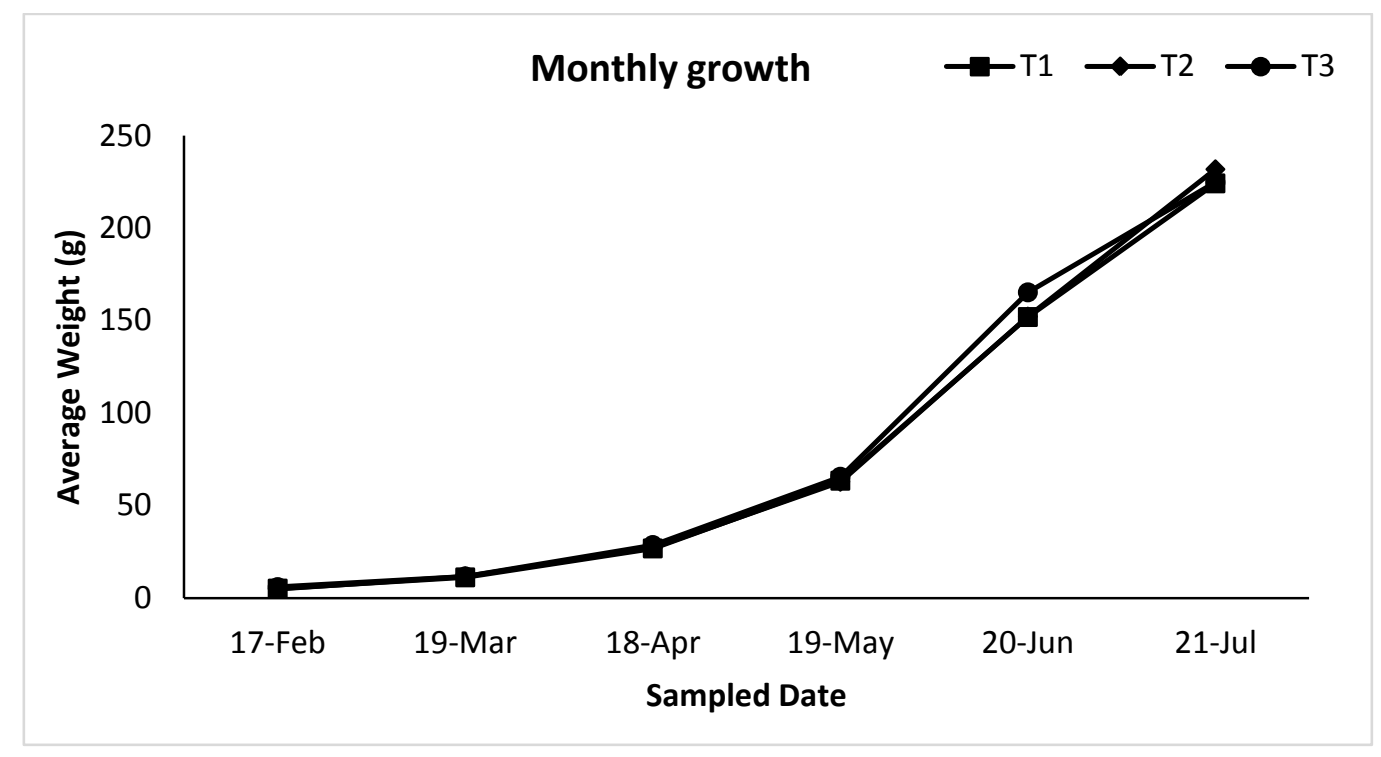

Fig. 1. Average monthly weight of fish in different treatments.

There was continuous rise in the value of average daily weight gain for first three month i.e. up to 19 May in all treatments (Figure 2). Later, average daily weight gain increased steeply for a month and then sudden fall was observed in all treatments during the last month. Highest average daily weight gain was observed in T3 at June, 20.

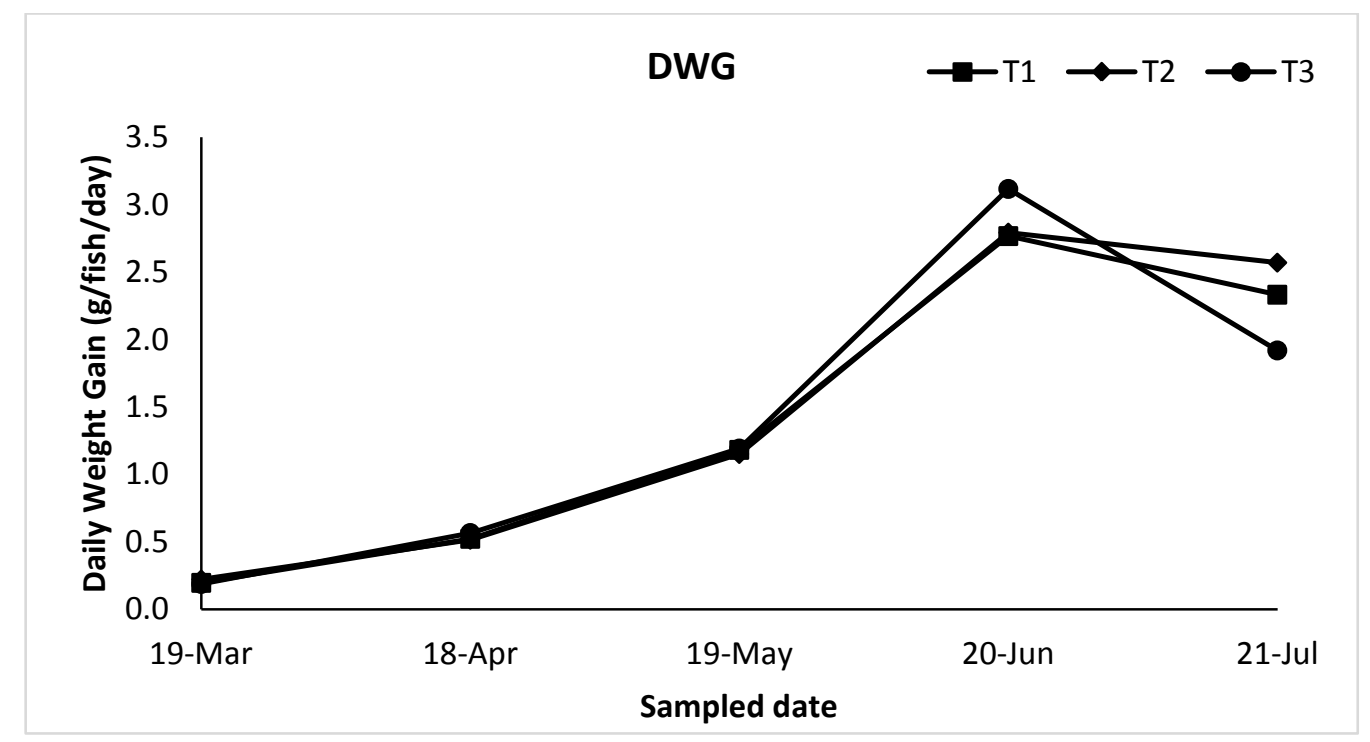

Fig. 2. Average monthly daily weight gain in different treatments.

AFCR (Apparent Food Conversion Ratio) at $19^{\text {th }}$ March for T1, T2 and T3 were 1.31, 1.26 and 1.71 respectively (Figure 3). AFCR of T3 came down but that of $\mathrm{T} 1$ and $\mathrm{T} 2$ shows similar pattern for the next month i.e. at $18^{\text {th }}$ April. After that FCR of T1, T2 and T3 maintained almost similar level for next three month and that was increased drastically in last month in all treatments. 


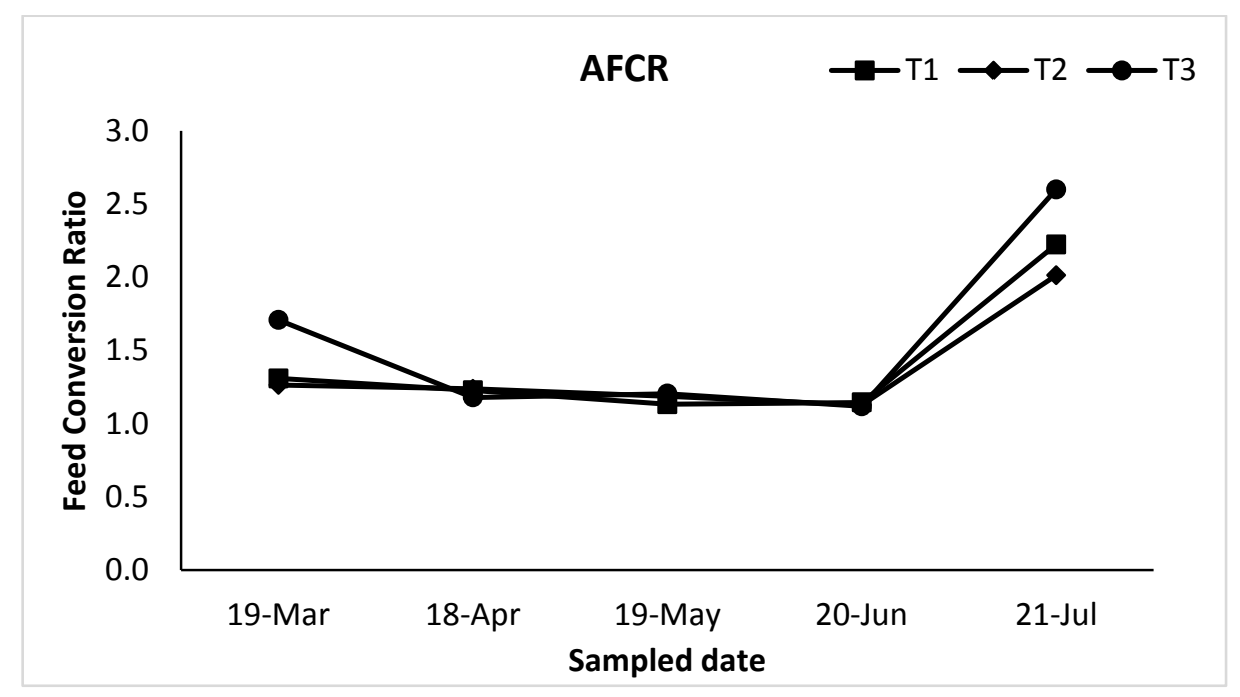

Fig. 3. AFCR in different treatments.

Maximum and minimum value of GFY (gross fish yield) and NFY (net fish yield) was observed in happa 1 and happa 6 respectively of same treatment $\mathrm{T} 2$, in which highest value of GFY was 2.33 $\mathrm{kg} / \mathrm{m}^{2} /$ year and lowest was $1.91 \mathrm{~kg} / \mathrm{m}^{2} /$ year. Similarly, maximum NFY was recorded as 2.28 $\mathrm{kg} / \mathrm{m}^{2} /$ year and minimum $1.86 \mathrm{~kg} / \mathrm{m}^{2} /$ year among different treatments.

However, there was no significant difference $(p>0.05)$ in final mean weight, final total weight, average DWG (daily weight gain), survival rate, extrapolated GFY, extrapolated NFY and AFCR in different treatments.

Table 3. Growth and production parameters in different treatment

\begin{tabular}{|l|l|l|l|}
\hline Parameters & T1 & T2 & T3 \\
\hline Mean stocking weight (g/fish) & $5.10 \pm 0.04$ & $4.92 \pm 0.10$ & $5.91 \pm 0.10$ \\
\hline Total stocking weight (g/m2) & $22.65 \pm 0.20$ & $21.85 \pm 0.46$ & $26.25 \pm 0.46$ \\
\hline Mean harvesting weight (g/fish) & $224.19 \pm 7.44^{\mathrm{a}}$ & $231.81 \pm 6.59^{\mathrm{a}}$ & $224.73 \pm 5.92^{\mathrm{a}}$ \\
\hline Total harvesting weight (g/m2) & $892.98 \pm 28.36^{\mathrm{a}}$ & $890.20 \pm 52.48^{\mathrm{a}}$ & $864.11 \pm 18.19^{\mathrm{a}}$ \\
\hline Average DWG (g/day/fish) & $1.41 \pm 0.05^{\mathrm{a}}$ & $1.46 \pm 0.04^{\mathrm{a}}$ & $1.41 \pm 0.04^{\mathrm{a}}$ \\
\hline Survival $(\%)$ & $90.00 \pm 10.0^{\mathrm{a}}$ & $86.67 \pm 11.55^{\mathrm{a}}$ & $86.67 \pm 5.77^{\mathrm{a}}$ \\
\hline Extrapolated GFY (kg/m2/yr) & $2.10 \pm 0.07^{\mathrm{a}}$ & $2.10 \pm 0.12^{\mathrm{a}}$ & $2.03 \pm 0.04^{\mathrm{a}}$ \\
\hline Extrapolated NFY (kg/m2/yr) & $2.05 \pm 0.07^{\mathrm{a}}$ & $2.04 \pm 0.12^{\mathrm{a}}$ & $1.97 \pm 0.04^{\mathrm{a}}$ \\
\hline Apparent Feed conversion ratio & $1.47 \pm 0.01^{\mathrm{a}}$ & $1.43 \pm 0.06^{\mathrm{a}}$ & $1.55 \pm 0.05^{\mathrm{a}}$ \\
\hline
\end{tabular}

\section{DISCUSSION}

Mustard oilcake (MOC) in the feed was replaced by linseed oil cake (LOC) at three different level $0 \%$, $50 \%$ and $100 \%$ to prepare three different types of diets. Replacement of MOC by LOC up to $100 \%$ did not significantly $(p>0.05)$ affect the weight, daily weight gain, survival, FCR, GFY and NFY. It supports that linseed meal may be a good alternative plant protein source in Nile Tilapia (Saidy \& Gaber, 2002). According to Hanafy (2006), there was no significant difference in growth performance of the Nile Tilapia fed on fish meal from those fed on plant protein diets in which soyabean meal was replaced with linseed meal at different level, supplemented with Yисca schidigera powder. Soltan (2005) replaced soybean meal with raw linseed, roasted and autoclaved linseed meal at various level, followed by replacing $25 \%$ of soybean meal protein by raw linseed meal in tilapia did not significantly affect body weight and body length but higher replacing level significantly decreased body weight, body length, 
weight gain and SGR. The best food conversion ratio was found in $25 \%$ raw linseed meal fed fish. Fish meal protein can be replaced up to $75 \%$ by linseed meal protein in fingerling of Nile Tilapia (Saidy \& Gaber, 2001).

The use of plant-derived materials as oil seed cake and leaf meal is limited by the presence of a widevariety of anti-nutritional substances, especially cassava leaf and linseed meal, due to cyanogen containing feed materials, which have generally shown reduced growth when compared to the respective control (Hossain \& Jauncey, 1989). However, dietary cyanide did not depress growth in Nile tilapia (Ng \& Wee, 1989). It agrees with the present experiment, where Nile Tilapia fed linseed replaced meal showed no growth depression.

Furthermore, growth performance was not significantly different when mustard meal was replaced partially or completely by linseed meal. It might be due to inadequate level of phosphorus in linseed meal (NRC, 1993) and presence of more anti-nutritional factors (including trypsin inhibitor) (Liener, 1980).

\section{CONCLUSION}

With the help of some growth parameters, growth performance of Nile Tilapia was observed in feeding trials on happa by replacing different level of mustard oilcake by linseed oilcake in the feed in three separate treatments. No significant difference $(p>0.05)$ was found among the growth parameters. Hence linseed oilcake can also be used in the culture of Tilapia in the place of mustard oil cake as feed supplementation. So, linseed meal can be used completely to replace mustard oil cake in Tilapia feed.

\section{ACKNOWLEDGEMENT}

Author is thankful to Central Department of Zoology (CDZ), Tribhuvan University, Kirtipur, Kathmandu and to the owners of 'Corona of Agriculture' Chitwan for providing research site and author is equally thankful to Head of Department and all staffs of CDZ.

\section{REFERENCES}

Bhandari, B. (1992). The current status of wetlands in Nepal. Country report presented at the Asian wetland Symposium, 14-20 October 1990, organized by Ramsar center Japan at Otsu/Kushiro, Japan.
Declercq, D. R. (2006). Quality of Western Canadian flaxseed, Canadian Grain Commission. www.graincanada.gc.ca.

Devi, N. S. and Devi, W. V. (2011). Nutrient Analysis of Some Poultry Feed stuff Locally Available in Manipur, India. World Journal of Dairy Food Science, 6 (2): 136-139.

El-Saidy, D. M. S. and Gaber, M. M. A. (2001). Linseed meat- its successful use as a partial and complete replacement for fish meal in practical diets for Nile tilapia Oreochromis niloticus. In: Proceeding of the Second International Conference on Animal Production and Health hi Semi-Arid Areas. Organized by Faculty of Environmental Agriculture Sciences, Suez Canal University, El-Arish-North Sinai, Egypt, pp. 635-643.

El-Saidy, D. M. S. and Gaber, M. M. A. (2002). Complete replacement of fish meal by soybean with the dietary L-lysine supplementation in Nile tilapia fingerlings. Journal of the World Aquaculture Society, 33: 297-306.

Fitzsimmons, K. (2000). Future trends of Tilapia culture in the Americas. In: B. A. Costapierce and J. E. Rakocy (eds.), Tilapia Aquaculture in the America, 2: 252-264.

Francis, G., Hariander, P. S., Makker, H. P. S. and Klaus, B. (2001). Anti-nutritional factors present in plant derived alternate fish feed ingredients and their effect in fish. Aquaculture 197:197-227.

Hanafy, M. A. (2006). Effect of replacement of soybean meal by linseed meal on growth performance and body composition of the nile tilapia (Oreochromis niloticus) cultured in concrete ponds. Egyptian Journal of Aquatic Biology and Fish, 10 (3): 185-200.

Hossain, M. A. and Jauncey, K. (1989). Studies on the protein, Energy and Aminoacid digestibility of common carp (Cyprinus carpio L). Aquaculture, 83: 59-72.

Liener, L. E. (1980). Toxic constituent of plant food stuffs, second edition. Academic press, New York.

Macintosh, D. J. and Little, D. C. (1995). Nile tilapia (O. Niloticus). In: BR Bromage and RJ Roberts (eds) Brood stock management and egg and larval quality. Blackwell science publication, London, pp. 227.

Mayombo, A. P.; Baldwin, P.; Wathelet, J. P.; Marlier, M. and Istasse, L. (1997). 
Incorporation of rapeseed meal obtained by presence in a flattening ratio at the bull. I. ingestion, digestibility and rumen fermentation. Annales de Zootechnie, 46 (1):57-70.

Ng, W. K. and Wee, K. L. (1989). The nutritive value of cassava leaf meal in pelleted feed for Nile tilapia. Aquaculture, 3: 45-58.

NRC (1993). Nutrient requirement of warm water fishes and shell fishes, revised edition. National Academy press. Washington D.C., USA.

Panth, M. B. (1993). Aquafeeds and feeding strategies in Nepal. In: New, M. B., Tacon, A. G. J. and Csavas, I., eds. Farm made Aqua feeds. Proceeding of FAO/ AADCP Regional Expert Cunsultation on Farm made aquafeeds, 14-18 December 1992, Bangkok, Thailand, FAO-RAPA/AADCP Bangkok, Thailand, pp. 297-316.

Pillay, T. V. R. (1999). Aquaculture principles and practices, Fishing Book news, pp. 57.

Sauvant, D., Perez, J. M. and Tran, G. (2004). INRA AFZ Tables of composition and nutritional value of raw materials for livestock: $2^{\text {nd }}$ edition, pp. 306.

Shrestha, J. (1994). Fishes, Fishing implements and Methods of Nepal. Smt, Gupta M. D.,
Lalitpur colony, Lwasker (Gwalior), India: 144.

Shrestha, M. K. (2004). Nile tilapia (O. Niloticus) culture in Nepal. Abstract, Fourth National conference on Science and Technology, March 23-26, 2004 RONAST, SSA-F-4.56p.

Shrestha, T. K. (1995). Fish catching in the Himalayan waters of Nepal. Shrestha B., Kathmandu, Nepal, pp. 247.

Slominski, B. A.; Kienzle, H. D.; Jieng, P.; Campbell, L. D.; Pickard, M. and Rakow, G. (1999). Chemical composition and nutritive value of canola-quality Sinapis Alba mustared. In Proceedings of the 10 International Rapeseed Congress Canberra. Australia, pp. 416-421.

Soltan, M. A. (2005). Partial and Total replacement of soybean meal by raw and heat treated linseed meal in Tilapia diet. Egyptian Journal of Nutrition and Feeds, 8 (1): 1091-1109.

Teichert-Coddington, G. R.; Popma, T. J and Lovshin, L. L. (1997). Attributes of tropical pond cultured fish. In: HS Egna and CE Boyd (eds) Dynamics of pond aquaculture. CRS press, Boca Raton, New York, pp. 183-198. 